Article

\title{
Effect of Biochar and Irrigation on Soybean-Rhizobium Symbiotic Performance and Soil Enzymatic Activity in Field Rhizosphere
}

\author{
Hua Ma ${ }^{1,2, *}$, Dilfuza Egamberdieva ${ }^{1,3}$, Stephan Wirth ${ }^{1}[$ and \\ Sonoko Dorothea Bellingrath-Kimura ${ }^{1,2}$ \\ 1 Leibniz Centre for Agricultural Landscape Research (ZALF), 15374 Müncheberg, Germany; \\ Dilfuza.Egamberdieva@zalf.de (D.E.); swirth@zalf.de (S.W.); belks@zalf.de (S.D.B.-K.) \\ 2 Faculty of Life Sciences, Humboldt-University of Berlin, 10099 Berlin, Germany \\ 3 Laboratory of Biogeography and Bioresource in Arid Land, Xinjiang Institute of Ecology and Geography, \\ Chinese Academy of Sciences, Urumqi 830001, China \\ * Correspondence: Hua.Ma@zalf.de; Tel.: +49-151-2689-1833
}

Received: 3 August 2019; Accepted: 4 October 2019; Published: 10 October 2019

\begin{abstract}
Nitrogen $(\mathrm{N})$ in soybean (Glycine max L.) plants derived from biological nitrogen fixation was shown to be a sustainable $\mathrm{N}$ resource to substitute for $\mathrm{N}$ fertilizer. However, the limited water supply in sandy soil is a critical factor for soybean nodulation and crop growth. This study investigated the potential mechanism of the effect of biochar and irrigation on the soybean-Rhizobium symbiotic performance and soil biological activity in a field trial. In the absence of $\mathrm{N}$ fertilizer, $10 \mathrm{tha}^{-1}$ of black cherry wood-derived biochar were applied under irrigated and rainfed conditions on an experimental, sandy field site. The plant biomass, plant nutrient concentrations, nodule number, nodule leghemoglobin content, soil enzyme activities, and soil-available nutrients were examined. Our results show that biochar application caused a significant increase in the nodule number by $35 \%$ in the irrigated condition. Shoot biomass and soil fluorescein diacetate hydrolytic activity were significantly increased by irrigation in comparison to the rainfed condition. The activity of soil protease reduced significantly, by $8 \%$, with the biochar application in the irrigated condition. Further, a linear correlation analysis and redundancy analysis performed on the plant, nodule, and soil variables suggested that the biochar application may affect soybean $\mathrm{N}$ uptake in the sandy field. Nodulation was enhanced with biochar addition, however, the plant $\mathrm{N}$ concentration and nodule $\mathrm{Lb}$ content remained unaffected.
\end{abstract}

Keywords: biochar; biological nitrogen fixation; leghemoglobin; nitrogen cycling; nodulation; soil enzymatic activity

\section{Introduction}

Nitrogen $(\mathrm{N})$ is a growth-limiting factor in ecosystems due to its crucial role in the synthesis of major bio-molecules [1], and thus is an especially paramount nutrient in agricultural crop production. Biological nitrogen fixation (BNF) in legumes was reported to provide considerable amounts of $\mathrm{N}$ and thus, improved soil productivity [2,3]. Biological nitrogen fixation accounted for $50-60 \%$ of soybean total $\mathrm{N}$ uptake by soybean according to a meta-analysis with 637 data sets in 108 field studies. In 2012, soybean contributed $67 \%$ of the world's protein meal supply [4]. However, abiotic stresses, including drought, threatened the growth and yield of legumes and other crops [5]. Grain legumes are sensitive to drought stress which may inhibit nodulation and $\mathrm{N}$ fixation [6,7]. Water deficit plays a major role in soybean nodulation and renders low $\mathrm{N}$ fixation due to its limitation on Rhizobium survival in the 
soil [8]. The process of root hair infection by Rhizobium and the formation of infection threads has also been found to be seriously inhibited by water deficits [9-11].

Biochar has been used widely as a soil additive to increase soil fertility through improving the water holding capacity [12,13], soil cation exchange capacity (CEC) [14], nutrient retention [15], and soil microbial and enzyme activities [16,17]. Furthermore, biochar has been considered as a Rhizobium inoculant carrier to increase the Rhizobium survival rate and the soybean nodulation rate $[18,19]$. In view of the facilitating Rhizobium survival, biochar can provide a habitat for microbes due to its porous structure, which has a high internal surface area and a high ability to adhere to soluble organic matter [20,21].

A sustainable $\mathrm{N}$ source for crop growth is from organic $\mathrm{N}$ mineralization. Biochar has been reported to have a negative effect on organic $\mathrm{N}$ mineralization. This was attributed to the biochar feedstock type, soil type and soil organic matter content [22,23]. On the other hand, the positive effect of biochar on nitrification has also been widely observed and it was further noted in pot experiments without planting $[1,24,25]$. No effect of biochar on soil nitrification was found in the field experiments by Castaldi et al. and Nelissen et al. [24,26]. These effects of biochar on nitrification imply that plant $\mathrm{N}$ uptake may influence the nitrification process. More intricacies in legume planted soil were observed. The $\mathrm{N}$ source from air and soil showed a suppression effect between each other since $\mathrm{N}$ addition inhibits nodulation and $\mathrm{N}$ fixation, whereas plant $\mathrm{N}$ uptake from BNF reduces plant $\mathrm{N}$ absorption from the soil $[27,28]$.

To understand the interactions between biochar, soil and plant, an analysis of soil enzyme activities can also assist. The total microbial activity renders a general estimation of organic matter decomposition in the soil [29]. The fluorescein diacetate (FDA) molecule is known to be hydrolyzed by a number of enzymes, including proteases, lipases, and esterases [30,31]. In addition, the FDA can also be hydrolyzed by bacteria and fungi [32]. Therefore, the hydrolytic activity of the FDA is considered as an indicator of total microbial activity. The FDA hydrolytic activity was shown to be increased by biochar addition in a pot experiment [15], whereas no effect was found in a field study [33]. Another extracellular enzyme, protease, catalyzes the hydrolysis of the protein components in the $\mathrm{N}$ mineralization process, especially in the initial stage [34]. The $\mathrm{N}$ derived from the mineralization of organic $\mathrm{N}$ by protease and peptidase catalysis represents $40 \%$ of the total soil $\mathrm{N}$ [35]. With respect to $\mathrm{N}$ related enzyme activity, biochar showed positive and negative effects on protease activity in recent studies $[21,25,36]$. It has been claimed that soil proteins can adhere to the surfaces of biochar pores. Accordingly, this may render a loss of available substrates in the soil and further result in a decrease of amino acids produced by protease catalysis [25]. In contrast, protease activity increased two-fold by the addition of biochar in a pot incubation experiment, however without planting [36,37]. The positive effect was generally attributed to the stimulation effect of biochar on microbial activity, as discussed by Ouyang et al. [37]. These results further suggest that the protease activity differed from a controllable pot ambience compared to realistic field surroundings, probably due to the complex and uncertain environmental conditions, such as weather, soil biota, and field heterogeneity.

As mentioned above, the effects of biochar on plant growth, plant nutrient uptake, soil nutrients availability and biological activity have been well documented. However, the impact of biochar and irrigation on the interrelationship among soil enzymes, soybean nodulation and crop growth as well as the potential of biochar on enhancing symbiotic performance of soybean under natural field conditions deserve more detailed investigations. Therefore, this study aimed to: (a) analyze the influence of biochar on plant growth under irrigated and rainfed conditions; (b) determine the effect of biochar and irrigation on soybean nodulation and $\mathrm{N}$ fixation; and (c) investigate the response of overall microbial activity (FDA hydrolytic activity) and protease activity to biochar amendment and irrigation. It was hypothesized that: (a) soybean nodulation, $\mathrm{N}$ fixation and plant biomass could be enhanced by increasing the water supply and biochar application; and (b) the soil enzyme activities and supply of available nutrients could be increased by biochar addition. 


\section{Materials and Methods}

\subsection{Study Site and Field Design}

The soybean field trial was conducted on a sandy soil (sand: $77 \%$, silt: $15 \%$ and clay: $8 \%$, Table 1 ) at the Leibniz Centre for Agricultural Landscape Research (ZALF), Müncheberg, Northeast Germany $\left(52.516074^{\circ} \mathrm{N}, 14.114823^{\circ} \mathrm{E}\right)$. The average temperature in Müncheberg was $19.0^{\circ} \mathrm{C}$ during the crop season from 12 May to 15 September 2016, and the precipitation was $450.9 \mathrm{~mm}$ (Figure 1A,B).

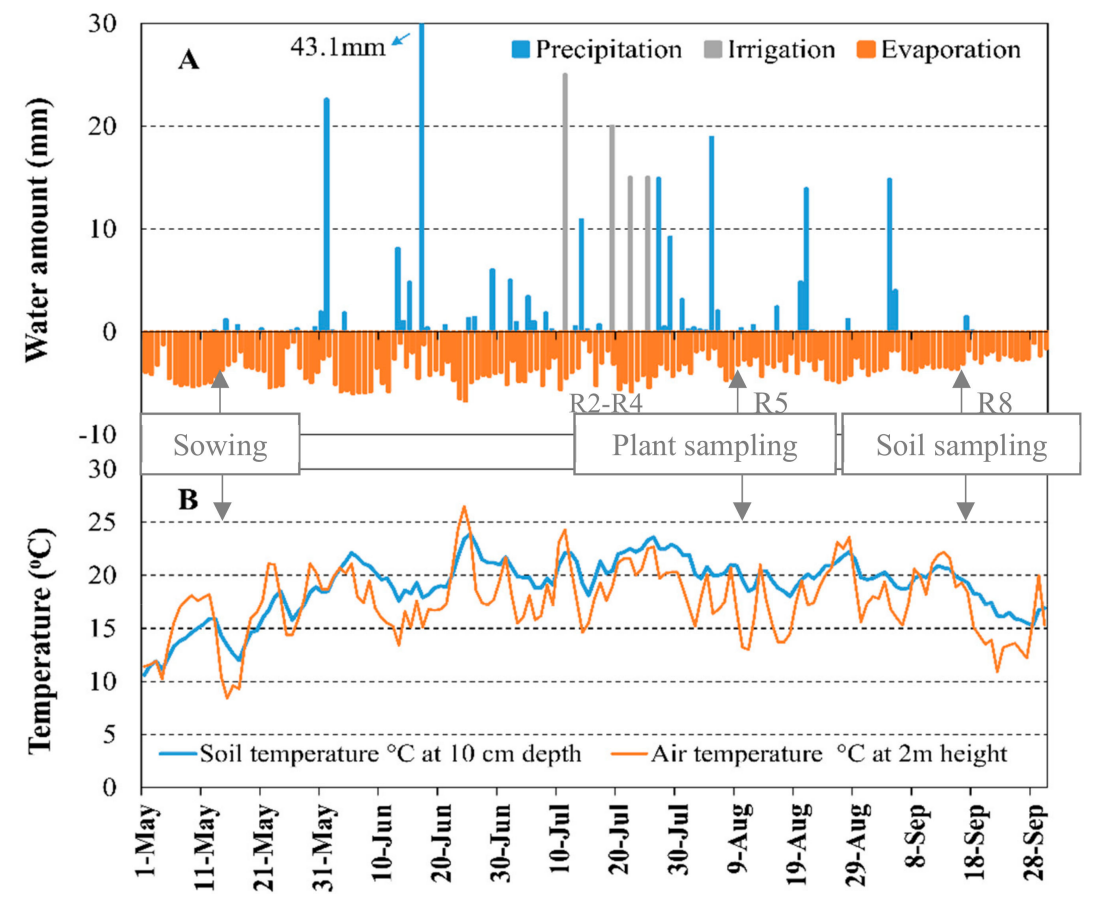

Figure 1. Weather condition during the experimental period. (A) Precipitation, evaporation, and irrigation and (B) air and soil temperature. R2 indicates reproductive stage 2 of soybean growth.

To reduce field heterogeneity, the field was designed along a 90-m-long transect with a width of $24.9 \mathrm{~m}$, and the transect was divided into two strips that were each $6.6 \mathrm{~m}$ wide (Figure 2). One strip was irrigated, and the other was not. Eight evenly distributed replications were set with a 7-m space in the transect. Each replication included four randomly arranged treatments, i.e., (a) $10 \mathrm{t} \mathrm{ha}^{-1}$ biochar application with irrigation, (b) $10 \mathrm{t} \mathrm{ha}^{-1}$ biochar application without irrigation (rainfed), (c) no biochar application (control) with irrigation, and (d) no biochar application (control) without irrigation (rainfed).

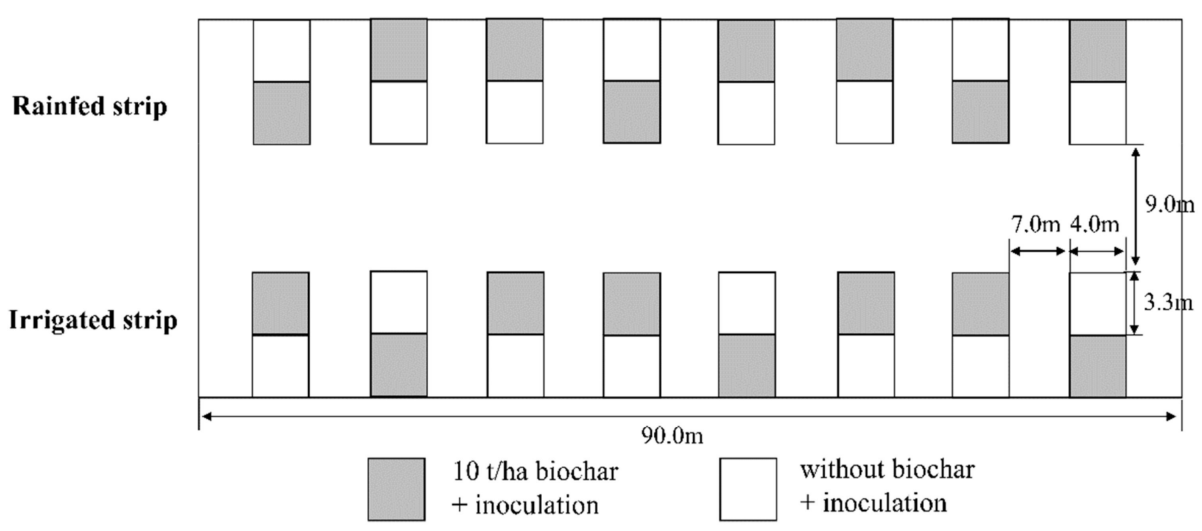

Figure 2. Field layout at ZALF Experimental Field 
All treatments received $100 \mathrm{~kg} \mathrm{ha}^{-1}$ of Triple-Superphosphate fertilizer $\left(46 \mathrm{~kg} \mathrm{P}_{2} \mathrm{O}_{5} \mathrm{ha}^{-1}\right)$. A total of $10 \mathrm{t} \mathrm{ha}^{-1}$ of biochar was applied to the biochar treatments. The biochar used in the study was produced at $450^{\circ} \mathrm{C}$ from black cherry wood (Terra Animaßonline shop, Meißen, Germany), with a particle size of less than $4 \mathrm{~mm}$. The biochar and soil properties are shown in Table 1.

Table 1. Soil and biochar characteristics.

\begin{tabular}{|c|c|c|c|c|c|c|c|c|c|c|c|c|c|c|}
\hline & \multicolumn{3}{|c|}{ Total $\left(\mathrm{g} \mathrm{kg}^{-1}\right)$} & \multicolumn{4}{|c|}{ Available (mg kg ${ }^{-1}$ ) } & \multirow{2}{*}{$\mathrm{C} / \mathrm{N}$} & \multirow{2}{*}{$\underset{\left(\mathrm{H}_{2} \mathrm{O}\right)}{\mathrm{pH}}$} & \multicolumn{4}{|c|}{$\mathrm{CEC}_{\text {eff }}\left(\mathrm{cmol}^{+} / \mathrm{kg}\right)$} & \multirow[b]{2}{*}{ Total } \\
\hline & C & $\mathbf{N}$ & $S$ & $\mathrm{Ca}$ & K & $\mathrm{Mg}$ & $\mathbf{P}$ & & & $\mathrm{Ca}$ & K & $\mathrm{Mg}$ & $\mathrm{Na}$ & \\
\hline Biochar & 415.08 & 3.75 & 0.58 & 8893 & 1151 & 471 & 326 & 110.6 & 8.41 & 21.49 & 1.69 & 2.69 & 0.063 & 22.68 \\
\hline Soil & 9.18 & 0.99 & 0.23 & 2103 & 1080 & 954 & 419 & 9.26 & 6.26 & 3.83 & 0.38 & 0.52 & 0.004 & 4.85 \\
\hline
\end{tabular}

Soil and biochar samples were collected before the field trial started.

Soybean (Glycine max L. var. sultana) seeds were obtained from the BASF Services Europe GmbH (Berlin, Germany) and planted in 8 rows for each plot with a seeding rate of 80 seeds $\mathrm{m}^{-2}$. The seeds were inoculated with Bradyrhizobium japonicum (HISTICK@Soy, BASF Services Europe GmbH) at a rate of $2 \times 10^{9} \mathrm{CFU} \mathrm{g}^{-1}$ before planting. The irrigation need was estimated by the decision support system, Irrigama, developed in ZALF (Wenkel et al. 1988; Mirschel and Wenkel 2004; Wenkel 2011), based on a model that was calculated according to the climate, soil quality, and development stage of the plants. The calculation depended on the initial data measured and estimated in Müncheberg. The irrigation water was supplied through a metal pipe armed with sprinklers on four days (11 July, 19 July, 22 July, and 25 July) and amounted to $75 \mathrm{~mm}$ in total (Figure 1A).

\subsection{Plant Sampling and Analysis}

Further, 90 days after planting (soybean reproductive growth stage 5), 15 plants were sampled from four points in each replicated plot for the measurements of biomass and plant nutrient contents. For plant sampling, the whole plant was carefully dug up at a depth of $25 \mathrm{~cm}$. The shoots were cut for measurements of dry weight and plant nutrient contents. Subsequently, the roots were stored at $4{ }^{\circ} \mathrm{C}$ for nodule sampling. The roots were rinsed with water and air-dried after the nodules were removed. All plant materials were dried in an oven at $68{ }^{\circ} \mathrm{C}$ for $48 \mathrm{~h}$. After the dry weight was determined, the materials were ground using a mill fitted with a 1-mm screen. Then, they were sub-sampled for the analysis of plant $\mathrm{N}$, phosphorus $(\mathrm{P})$, and potassium $(\mathrm{K})$ concentrations. The $\mathrm{N}$, $\mathrm{P}$ and $\mathrm{K}$ concentrations in plant tissue were analyzed with an inductively coupled plasma optical emission spectrometer (ICP-OES; iCAP 6300 Duo, ThermoFischer Scientific Inc., Waltham, MA, USA) via Mehlich-3 extraction (Sims, 2009). The yield was determined by harvesting five rows per $8.25-\mathrm{m}^{2}$ plot 126 days after planting. Then, the seeds were ground roughly to $2-3 \mathrm{~mm}$ particles and dried in an oven at $68^{\circ} \mathrm{C}$ for $48 \mathrm{~h}$. Subsequently, the dry weight of seed was determined.

\subsection{Soil Sampling and Analysis}

The root system of soybean was very carefully removed from a $0-15 \mathrm{~cm}$ depth, and root-adhered soil was collected and considered root-associated soil samples. The total carbon $(\mathrm{Ct})$, nitrogen $(\mathrm{Nt})$, and sulfur ( $\mathrm{St}$ ) contents of soil samples were determined by the dry combustion method using a CNS elemental analyzer (TruSpec, Leco Corp., St. Joseph, MI, USA) [38]. P, K, magnesium (Mg), and calcium (Ca) were analyzed by ICP-OES (iCAP 6300 Duo) via the method Mehlich-3 extraction [39]. The CEC was determined using the method ISO 13536:1995 by ICP-OES (iCAP 6300 Duo).

\subsection{FDA Hydrolytic Activity Assay}

The FDA hydrolytic activity was determined following the method of Green et al. [40]. A total of $0.5 \mathrm{mg}$ root-associated soil was added into a $50-\mathrm{ml}$ vial with subsequent addition of $25 \mathrm{~mL}$ of sodium phosphate (0.06 M; pH 7.6). Then, $0.25 \mathrm{~mL}$ of $4.9 \mathrm{mM}$ FDA substrate solution was added to all assay vials. The tightly capped vials were mixed and incubated in a water bath at $37^{\circ} \mathrm{C}$ for $1 \mathrm{~h}$. Subsequently, 
$1 \mathrm{~mL}$ of soil suspension was transferred to a $1.5-\mathrm{mL}$ tube and centrifuged at $8000 \mathrm{rpm}$ for $5 \mathrm{~min}$. The clear supernatant was measured at $490 \mathrm{~nm}$ against a reagent blank solution in a spectrophotometer. The controls followed the procedure described for the assay, but $0.25 \mathrm{~mL}$ acetone was added instead of the FDA substrate solution. The concentration of fluorescein released was calculated by reference to a standard curve from the results obtained with standards containing $0,0.019,0.095,0.952$, and $2.857 \mu \mathrm{g}$ $\mathrm{mL}^{-1}$ of fluorescein.

\subsection{Protease Activity Assay}

The protease activity was assayed using the method described by Ladd and Butler [41]. First, $0.5 \mathrm{~g}$ of root-associated soil was weighed into a glass vial. Then, $2.5 \mathrm{~mL}$ of phosphate buffer $(0.2 \mathrm{M}$, $\mathrm{pH} 7.0)$ and $0.5 \mathrm{~mL}$ of substrate N-benzoyl-L-arginine amide (BAA) solution (0.03 M) were added. Subsequently, the vials were capped and shaken in a water bath at $37^{\circ} \mathrm{C}$ with a rotary speed of $300 \mathrm{rpm}$ for $1 \mathrm{~h}$. After incubation, $2 \mathrm{~mL}$ of $\mathrm{KCl}(2 \mathrm{M})$ was added into the vials to cease the reaction, and $1 \mathrm{~mL}$ of the solution was pipetted into a micro tube and centrifuged at $6000 \mathrm{~g}$ for $10 \mathrm{~min}$. Then, $0.5 \mathrm{~mL}$ of the clear supernatant was mixed with $4.5 \mathrm{~mL}$ of distilled water, $2.5 \mathrm{~mL}$ of sodium salicylate- $\mathrm{NaOH}$ and $1 \mathrm{~mL}$ of sodium dichloroisocyanide solution. The reaction mixture was incubated at room temperature for $30 \mathrm{~min}$. The absorbance of the colored mixture was measured at $690 \mathrm{~nm}$ against a reagent blank solution in a spectrophotometer. The controls were performed to follow the procedure described for the assay, except the substrate BAA was added after incubation. The ammonium released was calculated by relating the measured absorbance at $690 \mathrm{~nm}$ to that of a calibration curve containing 0 , $1.0,1.5,2.0$, and $2.5 \mu \mathrm{g} \mathrm{NH}{ }_{4}^{+}-\mathrm{N} \mathrm{ml}^{-1}$.

\subsection{Nodule Sampling and Leghemoglobin Content Analysis}

The nodules were collected after the roots were rinsed with water. Subsequently, the numbers of nodules (nodule size $>1 \mathrm{~mm}$ ) were counted. Then, the nodules were sub-sampled for leghemoglobin ( $\mathrm{Lb})$ content analysis. The analysis of Lb content followed that of Wilson and Reisenauer (1963) [42], in which $0.5 \mathrm{mg}$ of crushed and ground nodule was mixed into $3 \mathrm{~mL}$ of Drabkin's solution. The supernatant was transferred to a $10-\mathrm{mL}$ tube after centrifugation at $500 \mathrm{~g}$ for $15 \mathrm{~min}$. The ground nodule was extracted twice more with $3 \mathrm{~mL}$ of Drabkin's solution, and the supernatants were combined. The volume was adjusted to $10 \mathrm{~mL}$ with Drabkin's solution, mixed, and centrifuged at 20,000 $\mathrm{g}$ for $30 \mathrm{~min}$. The analysis was standardized with a freshly prepared solution of bovine hemoglobin.

\subsection{Statistical Analysis}

The general linear model procedure was used for the analysis of variance, and multiple comparisons between treatments were tested at the $p<0.05$ level using the Duncan test. To characterize the relationship between various parameters, linear correlation analyses were applied, and Pearson's correlation coefficients were determined at $p<0.05$. These statistical analyses were performed with SPSS Statistics v22.0 (IBM Corp., Armonk, NY, USA). For further data exploration, a redundancy analysis (RDA) was used to clarify the dependent relationships between the explanatory variables (soil properties) and response variables (crop parameters) using the open source statistical language R v1.2.1335 (R Studio, Boston, MA, USA). The RDA used multiple linear regressions by allowing the regression of multiple response variables on multiple explanatory variables. Therefore, the RDA models a cause-effect relationship. The results of the RDA were shown on a triplot, on which the angles between the arrows of the response and explanatory variables denote correlations. The points for observations can be projected perpendicularly on the species lines and indicate the values [43]. 


\section{Result}

\subsection{Plant Biomass and Plant Nutrient Uptake}

There was no significant effect only by the application of biochar on soybean shoot biomass, root biomass and yield under the irrigated or rainfed condition (Table 2). However, the shoot biomass was significantly affected by irrigation. The shoot biomass, root biomass and yield were increased by irrigation by 11.7, 6.6 and 5.2\%, respectively. Likewise, plant shoot $\mathrm{N}$ and $\mathrm{P}$ concentrations were also significantly increased. The irrigated plots showed 10.6 and $15.4 \%$ greater $\mathrm{N}$ and $\mathrm{P}$ contents in the shoot, respectively. However, no significant differences for $\mathrm{N}$ and $\mathrm{P}$ concentration were found among the biochar treatments. The shoot $\mathrm{K}$ concentration showed no influence of either irrigation or biochar application.

Table 2. Effects of biochar on plant biomass, yield, and nutrient content.

\begin{tabular}{|c|c|c|c|c|c|c|c|}
\hline \multicolumn{2}{|c|}{ Treatment } & $\begin{array}{l}\text { Shoot DM } \\
\left(\mathrm{t} \mathrm{ha}^{-1}\right)\end{array}$ & $\begin{array}{c}\text { Root DM } \\
\left(\text { t ha }^{-1}\right)\end{array}$ & $\begin{array}{l}\text { Yield } \\
\left(\mathrm{t} \mathrm{ha} \mathbf{a}^{-1}\right)\end{array}$ & \multicolumn{3}{|c|}{ Shoot Nutrients Concentration $\left(\mathrm{g} \mathrm{kg}^{-1}\right)$} \\
\hline Rainfed & Control & $5.98 \pm 0.09 b$ & $0.68 \pm 0.03 a$ & $2.57 \pm 0.09 a$ & $21.51 \pm 0.31 b$ & $3.10 \pm 0.05 b$ & $20.49 \pm 0.18 a$ \\
\hline Irrigated & Control & $6.65 \pm 0.17 a$ & $0.75 \pm 0.05 a$ & $2.69 \pm 0.11 a$ & $23.31 \pm 0.74 a$ & $3.57 \pm 0.05 a$ & $21.36 \pm 0.51$ \\
\hline
\end{tabular}

Plants were sampled 90 days after planting. The means \pm SE followed by a different letter within each column are significantly different at $P<0.05$ using the Duncan-test, $n=8$.

\subsection{Nodule Number and Leghemoglobin Content}

Biochar increased the nodule number by 9.0 per plant under the irrigated conditions (Figure 3A) while no significant increase was detected under the rainfed condition. The Lb content was unchanged after the biochar application in both the irrigated and rainfed condition (Figure 3B).

A

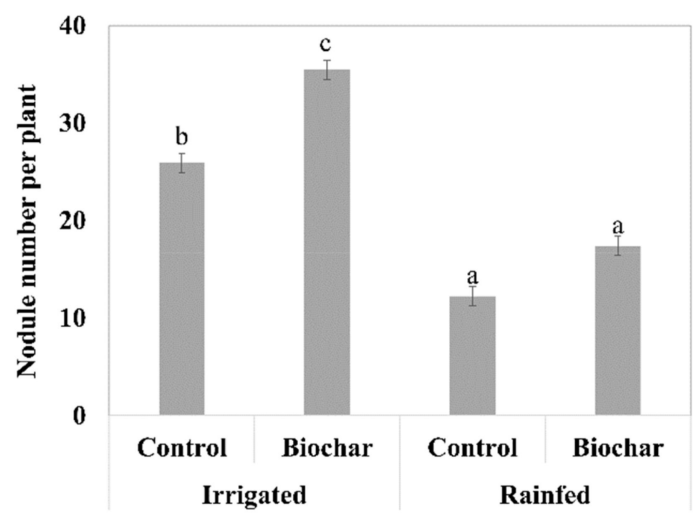

B

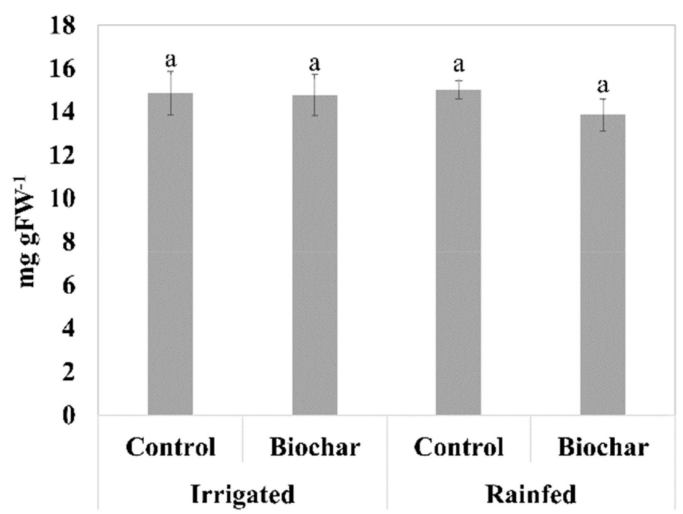

Figure 3. Effects of biochar on nodule number (A) and leghemoglobin content (B). Nodules were sampled 90days after planting. Error bars (standard error) followed by a different letter within each column are significantly different at $P<0.05$ using the Duncan-test, $n=8$. $\mathrm{g} \mathrm{FW}^{-1}$ : per gram of fresh weight.

In addition, there was a significantly positive correlation between the nodule number and shoot and root $\mathrm{N}$ concentration with the biochar application. The correlation coefficients were $0.63(p<0.01)$ and $0.72(p<0.01)$, respectively. Nevertheless, the correlation coefficient decreased to $0.54(p<0.05)$ between the nodule number and root $\mathrm{N}$ concentration when biochar was not applied. In addition, a significant correlation between the nodule number and shoot $\mathrm{N}$ concentration was not detected when biochar was not applied (Table 3). A negative correlation between Lb content and soil protease activity 
was observed in the biochar free treatments but no correlation was presented in the biochar applied treatments (Table 3).

Table 3. Correlations of plant biomass, plant nitrogen concentration, enzyme activity, nodule number, and leghemoglobin content indicated by the symbol (+/-) and the Pearson Correlation Coefficient.

\begin{tabular}{|c|c|c|c|c|c|c|}
\hline & Biochar & $\begin{array}{l}\text { Shoot Dry } \\
\text { Weight } \\
\left(\mathrm{t} \mathrm{ha}^{-1}\right)\end{array}$ & $\begin{array}{c}\text { Shoot } \mathrm{N} \\
\text { Concentration } \\
\left(\mathrm{g} \mathrm{kg}^{-1}\right)\end{array}$ & $\begin{array}{c}\text { Root } \mathrm{N} \\
\text { Concentration } \\
\left(\mathrm{g} \mathrm{kg}^{-1}\right)\end{array}$ & $\begin{array}{c}\text { Protease } \\
\left(\mu \mathrm{g} \mathrm{NH}{ }_{4}^{+}-\mathrm{N}\right. \\
\left.\mathrm{g}^{-1} \mathrm{~h}^{-1}\right)\end{array}$ & $\begin{array}{c}\text { FDA } \\
\left(\mu g^{-1} h^{-1}\right)\end{array}$ \\
\hline Nodule Number & + & 0.45 & $0.63 * *$ & $0.72 * *$ & -0.43 & 0.36 \\
\hline (per plant) & - & 0.38 & 0.47 & $0.54^{*}$ & -0.3 & $0.77 * *$ \\
\hline Leghemoglobin Content & + & 0.1 & -0.08 & -0.23 & 0.1 & 0.34 \\
\hline$\left(\mathrm{mg} \mathrm{gFW}^{-1}\right)$ & - & $0.50 *$ & 0.32 & 0.28 & $-0.61^{*}$ & 0.24 \\
\hline Protease & + & $-0.74^{* *}$ & $-0.54 *$ & -0.16 & 1 & -0.37 \\
\hline$\left(\mu \mathrm{g} \mathrm{NH}{ }_{4}^{+}-\mathrm{Ng}^{-1} \mathrm{~h}^{-1}\right)$ & - & -0.5 & -0.39 & -0.01 & 1 & -0.02 \\
\hline FDA & + & 0.4 & 0.32 & $0.56 *$ & -0.37 & 1 \\
\hline$\left(\mu \mathrm{g} \mathrm{g}^{-1} \mathrm{~h}^{-1}\right)$ & - & 0.42 & 0.28 & $0.87 * *$ & -0.02 & 1 \\
\hline
\end{tabular}

* $p<0.05,{ }^{* *} p<0.01$, symbol "+" and "-"showed in "Biochar" column indicate with biochar addition and without biochar addition (control), respectively.

\subsection{Soil Enzyme Activities and Soil Nutrients}

The activity of soil protease alter was significantly reduced by $8 \%$ in case of biochar application under irrigation, whereas no significant effect of biochar was presented for the rainfed condition (Figure 4A). The FDA hydrolytic activity was not significantly affected by the addition of biochar, but irrigation markedly increased the FDA hydrolytic activity by $52-63 \%$ in comparison to the treatments under the rainfed condition (Figure 4B). The protease activity was negatively correlated with shoot dry weight and shoot $\mathrm{N}$ concentration in biochar applied treatments, while no correlation was found for the treatments without biochar (Table 3). The correlation between the FDA hydrolytic activity and nodule number was strongly positive in biochar free treatments, whereas no correlation was shown in biochar applied treatments (Table 3). The soil Ct, Nt, P, K, Ca, and Mg contents, CEC, and pH were not significantly affected by biochar in both the irrigated and rainfed condition (Table 4).

A

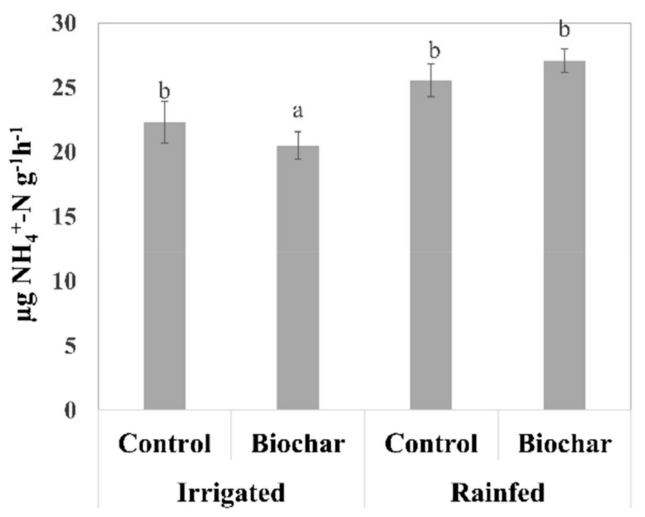

B

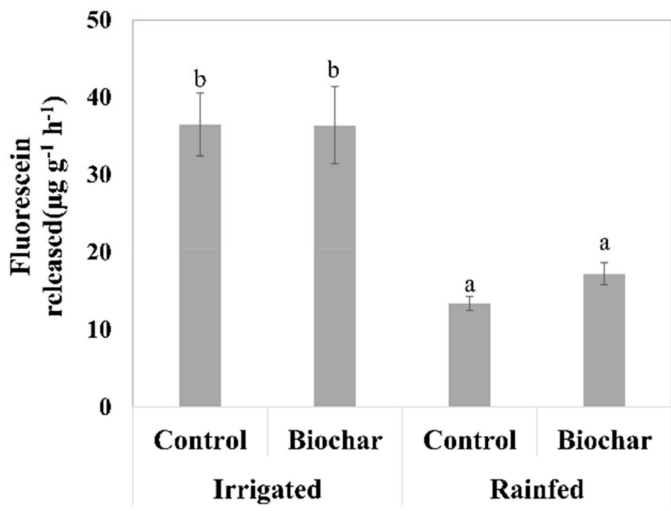

Figure 4. Effect of biochar on protease (A) and FDA hydrolytic activity (B) in the soil. The error bars (standard error) followed by a different letter within each column are significantly different at $P<0.05$ using the Duncan-test, $n=8$. 
Table 4. Effect of biochar on soil properties.

\begin{tabular}{|c|c|c|c|c|c|c|c|c|c|}
\hline \multicolumn{2}{|c|}{ Treatment } & \multicolumn{2}{|c|}{ Total $\left(\mathrm{g} \mathrm{kg}^{-1}\right)$} & \multicolumn{4}{|c|}{ Available (mg kg $\left.{ }^{-1}\right)$} & \multirow{2}{*}{$\begin{array}{c}\mathrm{CEC}_{\text {eff }} \\
\left(\mathrm{cmol}^{+}\right. \\
\left.\mathrm{kg}^{-1}\right)\end{array}$} & \multirow{2}{*}{$\underset{\left(\mathbf{H}_{2} \mathrm{O}\right)}{\mathrm{pH}}$} \\
\hline & & $\mathrm{C}$ & $\mathbf{N}$ & $\mathbf{P}$ & $\mathbf{K}$ & $\mathrm{Ca}$ & $\mathrm{Mg}$ & & \\
\hline \multirow[t]{2}{*}{ Rainfed } & Control & $\begin{array}{c}10.3 \pm \\
0.3 \mathrm{a}\end{array}$ & $\begin{array}{c}1.06 \pm \\
0.04 \mathrm{a}\end{array}$ & $389 \pm 7 a$ & $\begin{array}{c}1048 \pm \\
62 a\end{array}$ & $\begin{array}{c}1333 \pm \\
75 a\end{array}$ & $\begin{array}{c}900 \pm \\
46 a\end{array}$ & $\begin{array}{c}4.64 \pm \\
0.24 \mathrm{a}\end{array}$ & $\begin{array}{c}6.4 \pm \\
0.2 \mathrm{a}\end{array}$ \\
\hline & Biochar & $\begin{array}{c}11.5 \pm \\
0.4 \mathrm{a}\end{array}$ & $\begin{array}{c}1.10 \pm \\
0.04 \mathrm{a}\end{array}$ & $393 \pm 8 a$ & $\begin{array}{c}1034 \pm \\
51 a\end{array}$ & $\begin{array}{c}1420 \pm \\
79 a\end{array}$ & $\begin{array}{c}881 \pm \\
41 a\end{array}$ & $\begin{array}{c}5.01 \pm \\
0.27 \mathrm{a}\end{array}$ & $\begin{array}{c}6.6 \pm \\
0.1 \mathrm{a}\end{array}$ \\
\hline \multirow[t]{2}{*}{ Irrigated } & Control & $\begin{array}{c}10.4 \pm \\
0.4 \mathrm{a}\end{array}$ & $\begin{array}{c}1.06 \pm \\
0.05 \mathrm{a}\end{array}$ & $379 \pm 7 a$ & $\begin{array}{c}1032 \pm \\
40 a\end{array}$ & $\begin{array}{c}1364 \pm \\
141 \mathrm{a}\end{array}$ & $\begin{array}{c}935 \pm \\
31 \mathrm{a}\end{array}$ & $\begin{array}{c}4.73 \pm \\
0.41 \mathrm{a}\end{array}$ & $\begin{array}{c}6.3 \pm \\
0.2 \mathrm{a}\end{array}$ \\
\hline & Biochar & $\begin{array}{c}11.2 \pm \\
0.5 \mathrm{a}\end{array}$ & $\begin{array}{c}1.02 \pm \\
0.04 \mathrm{a}\end{array}$ & $383 \pm 5 a$ & $\begin{array}{c}1077 \pm \\
37 a\end{array}$ & $\begin{array}{c}1621 \pm \\
232 \mathrm{a}\end{array}$ & $\begin{array}{c}932 \pm \\
21 a\end{array}$ & $\begin{array}{c}5.16 \pm \\
0.46 \mathrm{a}\end{array}$ & $\begin{array}{c}6.7 \pm \\
0.2 \mathrm{a}\end{array}$ \\
\hline
\end{tabular}

The means \pm SE followed by a different letter within each column are significantly different at $p<0.05$ using the Duncan-test, $n=8$.

\subsection{Redundancy Analysis}

The data of the response variables (shoot dry weight, root dry weight, yield, shoot N, shoot $\mathrm{P}$, shoot $\mathrm{K}$, and nodule number) and for the explanatory variables (soil Ct, Nt, St, Ca, K, Mg, P, CEC, pH, protease and FDA hydrolytic activities, and nodule Lb content) were standardized before the RDA was performed in order to reveal interdependencies under the experimental field site conditions. The first six RDAs explained 38.04\%, 28.28\%, 14.31\%, 9.68\%, 5.49\% and $2.54 \%$ of the total variance in the crop and nodule parameters for the treatments with biochar, while for biochar free treatments the RDAs explained 41.79\%, 28.81\%, 16.26\%, 6.85\%, 3.59\%, and 2.12\%, respectively. The biochar-treated soil (Figure 5A) showed that: 1) shoot dry weight, shoot $\mathrm{N}$, and shoot $\mathrm{P}$ were negatively related with soil total $\mathrm{N}$ and protease activity, and 2) root dry weight was strongly related with FDA.

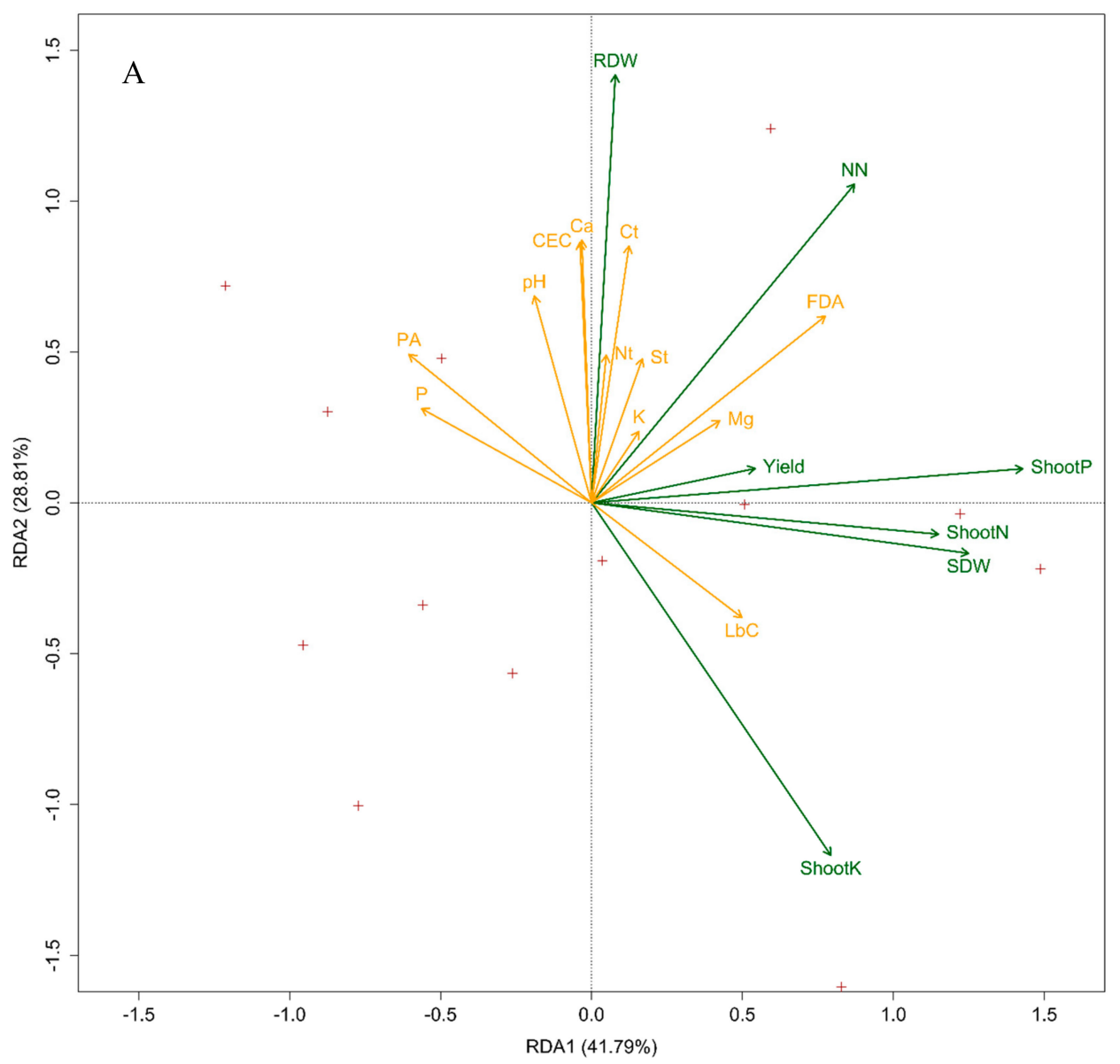

Figure 5. Cont. 


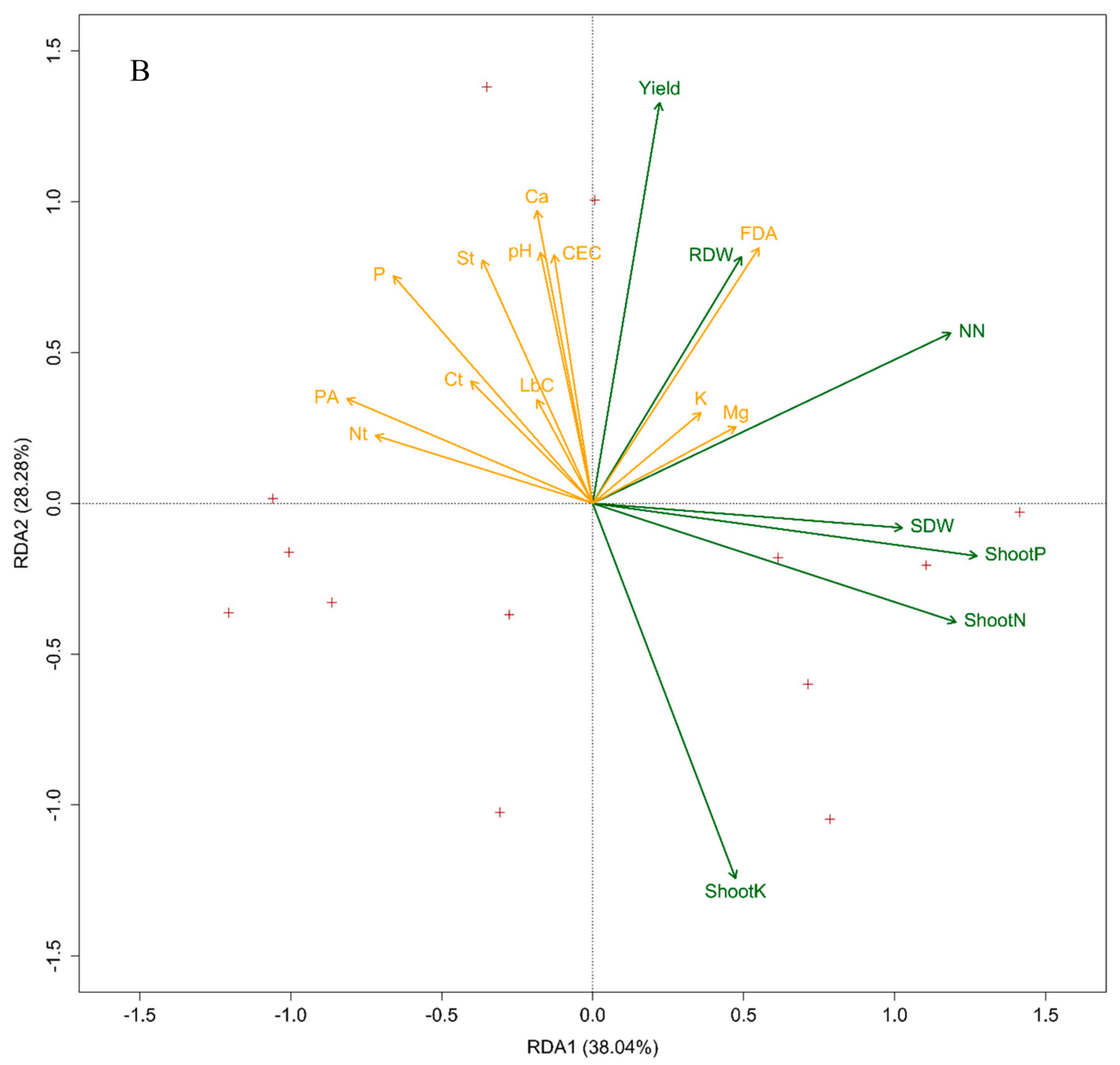

Figure 5. RDA-ordination triplot of variables in biochar treated soil (A) and control soil (B). Response variables are shown by green arrow; explanatory variables are shown by yellow arrow. Ct: total carbon content, LbC: leghemoglobin content, NN: nodule number, Nt: total nitrogen content, PA: protease activity, RDW: root dry weight, SDW: shoot dry weight, ShootK: shoot K concentration, ShootN: shoot N concentration, ShootP: shoot P concentration, St: total sulfur concentration.

For the control soil (Figure 5B) the most evident indications were that: (1) The nodule number was closely related with FDA; and (2) the root dry weight was closely related with $\mathrm{Ct}, \mathrm{Nt}$, $\mathrm{Ca}$ and CEC.

\section{Discussion}

\subsection{Plant Growth}

This study observed that the application of biochar to soil slightly increased soybean shoot biomass and grain yield, but the effect was not significant. In several recent studies, it has also been reported that biochar had no significant effect on plant growth or yield [44-47]. Joseph et al. reported that the interaction of biochar with environmental conditions is important to determine the contrasting effects of biochar on plant growth [48]. Moreover, the interaction also depends on the physicochemical properties of biochar. For example, plant growth was inhibited when sandy Ultisol was amended with biochar produced at $800^{\circ} \mathrm{C}$, whereas plant growth was significantly enhanced by biochar produced at $350^{\circ} \mathrm{C}$ [49]. In contrast, plant shoot biomass was enhanced after $75 \mathrm{~mm}$ irrigation water was supplied when the plants were undergoing water stress from 37 to 74 days after planting. 


\subsection{Nodulation, and Nitrogen Fixation}

Biochar increased the nodule number but showed no significant effect on Lb content. This indicates that the nodules from the biochar amended field and control field had a similar potential for $\mathrm{N}$ fixation as $\mathrm{Lb}$ regulates the release of bond oxygen to the bacteriods which are differentiated from Rhizobium-root cell symbiosomes. The bacteriods utilize oxygen for respiration and ATP providing for $\mathrm{N}$ fixation [50-52]. Therefore, leghemoglobin plays a critical role in nitrogen fixation of leguminous nodules [53]. Consequently, the stimulating impact of biochar on the nodule number indicated that the BNF might contribute more $\mathrm{N}$ to the shoot and root $\mathrm{N}$ concentration. A corresponding result was found in a pot experiment by Rondon et al., who showed that biochar addition increased the BNF-derived $\mathrm{N}$ in beans from $50 \%$ to $72 \%$ [54]. Additional evidence showed that biochar elevated the correlation between the nodule number and the shoot and root $\mathrm{N}$ concentration (Table 3). These results indicate the stimulating effect of biochar on BNF. Interestingly, biochar was also proven to have an inhibitory effect on plant $\mathrm{N}$ uptake by reducing $\mathrm{N}$ availability [54-56]. This decrease of $\mathrm{N}$ availability was reported to stimulate BNF [54].

The mechanism of enhancement of biochar on nodulation has been widely explained. Iijima et al. and Egamberdieva et al. pointed out that biochar is able to supply more pore space and air to nodule bacteria, which adhere to the biochar surface of pores in the soil $[19,57]$. The additional air supply from the pores may facilitate rhizobia respiration to enhance its survival rate in soil. In contrast, Pietikäinen et al. interpreted that the survival of bacteria, which are adsorbed onto biochar surfaces, is due to biochar protecting them in the soil [58]. Other research groups have elucidated the effect of biochar on nodulation caused by various signalling factors. Biochar can stimulate signalling for nodulation with the adsorption of flavonoids and Nod factors [59].

Nevertheless, there is a shortage of direct evidence to support those explanations, especially under field site conditions. Some evidence on examining the Rhizobium survival rate has been reported by Lehmann et al., who noted that the addition of biochar mixed with compost or farmyard manure increased the rhizobial cell counts and nodulation in soybean [60]. One specific experiment on biochar pore size was conducted to examine bacterial survival by Vanek and Thies [61]. This paper verified that Rhizobium tropici in biochar contained a maximum bacterial density of over $10^{8} \mathrm{CFU} \mathrm{g}^{-1}$ at a mean pore diameter of between 10 and $15 \mu \mathrm{m}$ for up to six months.

In the rainfed condition, however, our result did not manifest a significant increase of nodulation with the biochar addition. However, it was hypothesized that biochar application would be beneficial on nodulation. A water deficit can cause major effects on nodulation [8]. Zahran et al. illustrated that osmotic stress may lead to an alteration in the Rhizobium-host plant recognition process [62]. As this study recorded, the precipitation was only $34.3 \mathrm{~mm}$ from 37 to 74 days after planting (Figure 1A). The serious inhibition on root hair infection by Rhizobium and the formation of infection threads during water deficit has been observed frequently [9-11]. It is very likely that a water deficit played a more crucial role in nodulation than the beneficial effect of biochar under the rainfed condition in our study.

\subsection{Soil Biological Activity}

It was observed that the FDA hydrolytic activity, a measure of the overall microbial activity, was significantly higher in irrigated soil than in rainfed soil (Figure 4). In terms of suboptimal water supply, Elbl demonstrated that drought stress has a significant deleterious effect on the microbial activity in soil [63]. Furthermore, Hueso et al. illustrated that drought severely decreased the soil microbial community size and activity, as reflected by the significantly lower microbial biomass C and ATP values as well as enzyme activities [64]. In this study, the low precipitation from 86 days after planting to harvesting time may have induced drought stress to the microbial community. The precipitation and evaporation were 45.7 and $173.3 \mathrm{~mm}$ respectively from 86 days after planting to harvesting time.

Several articles have reported that rhizobia may increase enzyme activity in the soil-root zone. Siczek and Lipiec found that Rhizobium inoculation consistently increased the activities of several enzymes in the rhizosphere [65]. Particularly, the rhizobial inoculation was observed to enhance soil 
FDA hydrolytic activity in a two-year field trial [66]. Furthermore, biochar and its highly porous structure can protect microorganisms from being grazed by predators $[67,68]$. Therefore, Rhizobium colonizing in biochar pores might diminish its positive effect on soil enzyme activity. Furthermore, the biochar addition eliminated the strong correlation between the FDA hydrolytic activity and nodule number. Moreover, in treatments without biochar, the loading and vector angle in RDA of FDA hydrolytic activity and nodule number indicated a positive relation but not for the biochar treatments.

Soil protease activity decreased in biochar-amended soil under the irrigated condition. Geisseler and Horwath observed that the high uptake rate of the additional $\mathrm{N}$ by plant resulted in the decreased need for $\mathrm{N}$ from the hydrolysis of $\mathrm{N}$ compounds [69]. They suggested that the protease activity depends on the $\mathrm{N}$ demand of plants. The $\mathrm{N}$ supplied by BNF may also reduce the $\mathrm{N}$ need from the soil $\mathrm{N}$ mineralization for plants use. Consequently, protease synthesis may be inhibited. Additional evidence in the RDA triplot showed that biochar has an enhancing effect on the negative relationships between protease activity and plant shoot dry weight/shoot $\mathrm{N}$ concentration. The reverse direction between the vector of protease activity and plant shoot dry weight/shoot $\mathrm{N}$ in the RDA indicated a negative correlation, whereas the angle closing to $180^{\circ}$ between the vector of protease activity and plant shoot dry weight/shoot $\mathrm{N}$ in biochar treatments indicated a strong relation. Additionally, as discussed in the prior section, the plants which were grown in the soil without the biochar application were supposed to take more $\mathrm{N}$ from the soil than those grown in biochar-added soil. Therefore, in the control soil, the $\mathrm{N}$ that is taken up from the soil mostly originated from $\mathrm{N}$ mineralization and inherent soil mineral $\mathrm{N}$ since no $\mathrm{N}$ fertilization was performed during the cropping period. This may explain why the protease activity was significantly higher in biochar free treatments than in biochar applied treatments.

\section{Conclusions}

We conclude that the application of black cherry wood biochar had a positive effect on the symbiotic performance of Bradyrhizobium japonicum with soybean, but only in the irrigated condition on our experimental field site. Nevertheless, plant growth was not significantly enhanced by biochar addition but improved by the water supply via irrigation. Further analysis reveals that nodulation was enhanced with biochar addition, however, the plant $\mathrm{N}$ concentration and nodule Lb content remained unaffected. The water supply played a more dominant role than biochar addition concerning the soil total microbial activity due to significantly higher FDA hydrolytic activity in the irrigated condition than in the rainfed condition. On the other hand, the biochar application reduced the soil protease activity in the irrigated condition. Under field conditions, the combination of soybean and biochar can be a promising approach to reduce $\mathrm{N}$ fertilization and relieve environmental cost, especially for sandy regions which are suffering from low soil productivity. However, adequate water supply is still a prerequisite for the promotion of crop production.

Author Contributions: Data curation, H.M.; formal analysis, H.M.; methodology, H.M., D.E., S.W. and S.D.B.K; resources, D.E. and S.D.B.K.; supervision, D.E. and S.D.B.K; writing-original draft, H.M.; writing-review \& editing, H.M., D.E., S.W., and S.D.B.K.

Acknowledgments: This research was sponsored by INNISOY project (Innovation Network to Improve Soybean Production under the Global Change). We thank all technicians at the ZALF Research Station, Müncheberg, for their support in the field experiment. YingYing Ma is acknowledged for support in statistics and editing.

Conflicts of Interest: Authors declare no conflicts of interest.

\section{References}

1. Hagemann, N.; Harter, J.; Behrens, S. Elucidating the Impacts of Biochar Applications on Nitrogen Cycling Microbial Communities. Biochar Appl. Essent. Soil Microb. Ecol. 2016, 7, 163-198. [CrossRef]

2. Salvagiotti, F.; Cassman, K.G.; Weiss, A.; Dobermann, A. Nitrogen uptake, fixation and response to N fertilizer in soybeans. Field Crop Res. 2008, 65, 137-149. [CrossRef] 
3. Santi, C.; Bogusz, D.; Franche, C. Biological nitrogen fixation in non-legume plants. Ann. Bot. 2013, 111, 743-767. [CrossRef] [PubMed]

4. Dos Santos Silva, F.C.; Sediyama, T.; de Ca’ssia Teixeira Oliveira, R.; Bore’́m, A.; da Silva, F.L.; Bezerra, A.R.G.; da Silva, A.F. Economic Importance and Evolution of Breeding. In Soybean Breeding; Da Silva, F.L., Gomes Bezerra, A.R., da Silva, A.F., Eds.; Springer: Cham, Switzerland, 2017; p. 3. [CrossRef]

5. Bodner, G.; Nakhforoosh, A.; Kaul, H.P. Management of crop water under drought: A review. Agron. Sustain. Dev. 2015, 35, 401-442. [CrossRef]

6. Bouhmouch, I.; Souad-Mouhsine, B.; Brhada, F.; Aurag, J. Influence of host cultivars and Rhizobium species on the growth and symbiotic performance of Phaseolus vulgaris under salt stress. J. Plant Physiol. 2005, 162, 1103-1113. [CrossRef] [PubMed]

7. Farooq, M.; Gogoi, N.; Barthakur, S.; Baroowa, B.; Bharadwaj, N.; Alghamdi, S.S.; Siddique, K.H.M. Drought Stress in Grain Legumes during Reproduction and Grain Filling. J. Agron. Crop Sci. 2017, 203, 81-102. [CrossRef]

8. Mahler, R.L.; Wollum, A.G., II. The influence of soil water potential and soil texture on the survival of Rhizobium japonicum and Rhizobium leguminosarum isolates in the soil. J. Soil Sci. Soc. Am. 1981, 45, 761-766. [CrossRef]

9. Sprent, J.I. The Effects of Water Stress on Nitrogen-Fixing Root Nodules. New Phytol. 1971, 70, 9-17. [CrossRef]

10. Graham, P.H. Stress tolerance in Rhizobium and Bradyrhizobium, and nodulation under adverse soil conditions. Can. J. Microbiol. 1992, 38, 475-484. [CrossRef]

11. Serraj, R.; Vadez, V.; Denison, R.F.; Sinclair, T.R. Involvement of Ureides in Nitrogen Fixation Inhibition in Soybean1. Plant Physiol. 1999, 119, 289-296. [CrossRef]

12. Yu, O.Y.; Raichle, B.; Sink, S. Impact of biochar on the water holding capacity of loamy sand soil. Int. J. Energy Environ. Eng. 2013, 4, 44. [CrossRef]

13. Oram, N.J.; van de Voorde, T.F.J.; Ouwehand, G.-J.; Bezemer, T.M.; Mommer, L.; Jeffery, S.; Groenigen, J.W. Van. Soil amendment with biochar increases the competitive ability of legumes via increased potassium availability. Agric. Ecosyst. Environ. 2014, 191, 92-98. [CrossRef]

14. Jien, S.H.; Wang, C.S. Effects of biochar on soil properties and erosion potential in a highly weathered soil. Catena 2013, 110, 225-233. [CrossRef]

15. Chan, K.Y.; Van Zwieten, L.; Meszaros, I.; Downie, A.; Joseph, S. Agronomic values of greenwaste biochar as a soil amendment. Aust. J. Soil Res. 2007, 45, 629-634. [CrossRef]

16. Kolton, M.; Harel, Y.M.; Pasternak, Z.; Graber, E.R.; Elad, Y.; Cytryn, E. Impact of biochar application to soil on the root-associated bacterial community structure of fully developed greenhouse pepper plants. Appl. Environ. Microbiol. 2011, 77, 4924-4930. [CrossRef] [PubMed]

17. Egamberdieva, D.; Davranov, K.; Wirth, S.; Hashem, A.; Abd_Allah, E.F. Impact of soil salinity on the plant-growth—Promoting and biological control abilities of root associated bacteria. Saudi J. Biol. Sci. 2017, 24, 1601-1608. [CrossRef] [PubMed]

18. Głodowska, M.; Schwinghamer, T.; Husk, B.; Smith, D. Biochar Based Inoculants Improve Soybean Growth and Nodulation. Agric. Sci. 2017, 8, 1048-1064. [CrossRef]

19. Egamberdieva, D.; Hua, M.; Wirth, S.; Bellingrath-Kimura, S.D. Potential effects of biochar-based microbial inoculants in agriculture. Environ. Sustain. 2018, 1, 19-24. [CrossRef]

20. Lehmann, J.; Rillig, M.C.; Thies, J.; Masiello, C.A.; Hockaday, W.C.; Crowley, D. Biochar effects on soil biota-A review. Soil Biol. Biochem. 2011, 43, 1812-1836. [CrossRef]

21. Thies, J.E.; Rillig, M.C.; Graber, E.R. Biochar effects on the abundance, activity and diversity of the soil biota. In Biochar for Environmental Managagement_Science, Technology and Implementation, 2nd ed.; Routledge: London, UK, 2015; pp. 327-390. Available online: https://www.routledge.com/products/9780415704151 (accessed on 6 October 2019).

22. Cheng, Y.; Cai, Z.C.; Chang, S.X.; Wang, J.; Zhang, J.B. Wheat straw and its biochar have contrasting effects on inorganic $\mathrm{N}$ retention and $\mathrm{N}_{2} \mathrm{O}$ production in a cultivated Black Chernozem. Biol. Fertil. Soils 2012, 48, 941-946. [CrossRef]

23. Gul, S.; Whalen, J.K. Biochemical cycling of nitrogen and phosphorus in biochar-amended soils. Soil Biol. Biochem. 2016, 103, 1-15. [CrossRef] 
24. Nelissen, V.; Rütting, T.; Huygens, D.; Staelens, J.; Ruysschaert, G.; Boeckx, P. Maize biochars accelerate short-term soil nitrogen dynamics in a loamy sand soil. Soil Biol. Biochem. 2012, 55, 20-27. [CrossRef]

25. Prommer, J.; Wanek, W.; Hofhansl, F.; Trojan, D.; Offre, P.; Urich, T.; Schleper, C.; Sassmann, S.; Kitzler, B.; Soja, G.; et al. Biochar decelerates soil organic nitrogen cycling but stimulates soil nitrification in a temperate arable field trial. PLoS ONE 2014, 9, e86388. [CrossRef] [PubMed]

26. Castaldi, S.; Riondino, M.; Baronti, S.; Esposito, F.R.; Marzaioli, R.; Rutigliano, F.A.; Vaccari, F.P.; Miglietta, F. Impact of Biochar Application to a Mediterranean Wheat Crop on Soil Microbial Activity and Greenhouse Gas Fluxes. Chemosphere 2011, 85, 1464-1471. [CrossRef] [PubMed]

27. Appleby, C.A. Leghemoglobin and rhizobium respiration. Annu. Rev. Plant Physiol. 1984, 35, 443-478. [CrossRef]

28. Gundale, M.J.; Bach, L.H.; Nordin, A. The impact of simulated chronic nitrogen deposition on the biomass and $\mathrm{N}_{2}$-fixation activity of two boreal feather mosscyanobacteria associations. Biol. Lett. 2013, 9. [CrossRef]

29. Heal, O.W.; McClean, S.F., Jr. Comparative productivity in ecosystems-secondary productivity. In Unifying Concepts in Ecology; Dobben, W.H., Lowe-McConnell, R.H., Eds.; W. Junk B.V. Publishers: Hague, The Netherlands, 1975; pp. 89-108.

30. Schnurer, J.; Rosswall, T. Fluorescein diacetate hydrolysis as a measure of total microbial activity in soil and litter. Appl. Environ. Microbiol. 1982, 43, 1256-1261. [CrossRef] [PubMed]

31. Renella, G.; Landi, L.; Nannipieri, P. Hydrolase activities during and after the chloroform fumigation of soil as affected by protease activity. Soil Biol. Biochem. 2002, 34, 51-60. [CrossRef]

32. Battin, T.J. Assessment of fluorescein diacetate hydrolysis as a measure of total esterase activity in natural stream sediment biofilms. Sci. Total Environ. 1997, 198, 51-60. [CrossRef]

33. Cao, Y.; Ma, Y.; Guo, D.; Wang, Q.; Wang, G. Chemical properties and microbial responses to biochar and compost amendments in the soil under continuous watermelon cropping. Plantsoil Environ. 2017, 63, 1-7. [CrossRef]

34. Maddela, N.R.; Golla, N.; Vengatampalli, R. Soil Enzymes: Influence of Sugar Industry Effluents on Soil Enzyme Activities; Springer: Cham, Switzerland, 2017; Available online: https://oi.org/10.1007/978-3-319-42655-6 (accessed on 6 October 2019).

35. Schulten, R.; Schnitzer, M. The chemistry of soil organic nitrogen: A review. Biol Fertil Soils 1998, $26,1-15$. [CrossRef]

36. Khadem, A.; Raiesi, F. Influence of biochar on potential enzyme activities in two calcareous soils of contrasting texture. Geoderma 2017, 308, 149-158. [CrossRef]

37. Ouyang, L.; Tang, Q.; Yu, L.; Zhang, R. Effects of amendment of different biochars on soil enzyme activities related to carbon mineralisation. Soil Res. 2014, 52, 706-716. [CrossRef]

38. Nelson, D.W.; Sommers, L.E. Total carbon, organic carbon and organic matter. In Methods of Soil Analysis; Part 2. Agronomy Monographs 9; Page, A.L., Ed.; ASA; SSSA: Madison, WI, USA, 1982; pp. 539-579.

39. Sims, J.T. Soil test phosphorus: Principles and methods. In Methods of Phosphorus Analysis for Soils, Sediments, Residuals and Waters, 2nd ed.; Kovar, J.L., Pierzynski, G.M., Eds.; Southern Cooperative Series Bulletin No. 408; Virginia Tech University: Blacksburg, VA, USA, 2009; pp. 9-19.

40. Green, V.S.; Stott, D.E.; Diack, M. Assay for Fluorescein Diacetate Hydrolytic Activity: Optimization for Soil Samples. Soil Biol. Biochem. 2006, 38, 693-701. [CrossRef]

41. Ladd, J.N.; Butler, J.H.A. Short-term assays of soil proteolytic enzyme activities using proteins and dipeptide derivatives as substrates. Soil Biol. Biochem. 1972, 4, 19-30. [CrossRef]

42. Wilson, D.O. and Reisenauer, H.M. Determination of leghemoglobin in legume nodules. Anal. Biochem. 1963, 6, 27-30. [CrossRef]

43. Zuur, A.F.; Ieno, E.N.; Smith, G.M. Principal component analysis and redundancy analysis 12. In Analysing Ecological Data; Springer: New York, NY, USA, 2007; pp. 210-219.

44. Borchard, N.; Siemens, J.; Ladd, B.; Möller, A.; Amelung, W. Application of biochars to sandy and silty soil failed to increase maize yield under common agricultural practice. Soil Tillage Res. 2014, 144, 184-194. [CrossRef]

45. Tammeorg, P.; Simojoki, A.; Mäkelä, P.; Stoddard, F.L.; Alakukku, L.; Helenius, J. Biochar application to a fertile sandy clay loam in boreal conditions: Effects on soil properties and yield formation of wheat, turnip rape and faba bean. Plant Soil 2014, 374, 89-107. [CrossRef] 
46. Nguyen, D.H.; Scheer, C.; Rowlings, D.W.; Grace, P.R. Rice husk biochar and crop residue amendment in subtropical cropping soils: Effect on biomass production, nitrogen use efficiency and greenhouse gas emissions. Biol. Fertil. Soils 2016, 52, 261-270. [CrossRef]

47. Al-Wabel, M.I.; Hussain, Q.; Usman, A.R.A.; Ahmad, M.; Abduljabbar, A.; Sallam, A.S.; Ok, Y.S. Impact of biochar properties on soil conditions and agricultural sustainability: A review. Land Degrad. Dev. 2017, 29, 2124-2161. [CrossRef]

48. Joseph, S.D.; Camps-Arbestain, M.; Lin, Y.; Munroe, P.; Chia, C.H.; Hook, J.; van Zwieten, L.; Kimber, S.; Cowie, A.; Singh, B.P.; et al. An Investigation into the reactions of biochar in soil. Australian J. Soil Res. 2010, 48, 501-515. [CrossRef]

49. Butnan, S.; Deenik, J.L.; Toomsan, B.; Antal, M.J.; Vityakon, P. Biochar characteristics and application rates affecting corn growth and properties of soils contrasting in texture and mineralogy. Geoderma 2015, 237, 105-116. [CrossRef]

50. Delwiche, C.C. Nitrogen Cycle. Sci. Am. 2001, 223, 9-13. [CrossRef]

51. Singh, S.; Varma, A. Structure, Function, and Estimation of Leghemoglobin. In Rhizobium Biology and Biotechnology; Hansen, A.P., Choudhary, D.K., Agrawal, P.K., Varma, A., Eds.; Springer: Basel, Switzerland, 2017; Volume 50, pp. 309-330. [CrossRef]

52. Clúa, J.; Roda, C.; Zanetti, M.E.; Blanco, F.A. Compatibility between Legumes and Rhizobia for the Establishment of a Successful Nitrogen-Fixing Symbiosis. Genes 2018, 9, 125. [CrossRef] [PubMed]

53. Ohyama, T.; Yashima, H.; Tanabata, S.; Ishikawa, S.; Sato, T.; Nishiwaki, T.; Ohtake, N.; Sueyoshi, K.; Ishii, S.; Fujimaki, S. Effect of Nitrate on Nodulation and Nitrogen Fixation of Soybean. Soybean Physiol. Biochem. 2011, 333-364. [CrossRef]

54. Rondon, M.A.; Lehmann, J.; Ramírez, J.; Hurtado, M. Biological nitrogen fixation by common beans (Phaseolus vulgaris L.) increases with bio-char additions. Biol. Fertil. Soils 2007, 43, 699-708. [CrossRef]

55. Kammann, C.I.; Linsel, S.; Gößling, J.W.; Koyro, H.W. Influence of biochar on drought tolerance of Chenopodium quinoa Willd and on soil-plant relations. Plant Soil 2011, 345, 195-210. [CrossRef]

56. Prendergast-Miller, M.T.; Duvall, M.; Sohi, S.P. Localisation of nitrate in the rhizosphere of biochar-amended soils. Soil Biol. Biochem. 2011, 43, 2243-2246. [CrossRef]

57. Iijima, M.; Yamane, K.; Izumi, Y.; Daimon, H.; Motonaga, T. Continuous Application of Biochar Inoculated with Root Nodule Bacteria to Subsoil Enhances Yield of Soybean by the Nodulation Control using Crack Fertilization Technique. Plant Prod. Sci. 2015, 18, 197-208. [CrossRef]

58. Pietikainen, J.; Kiikkila, O.; Fritze, H. Charcoal as a habitat for microbes and its effect on the microbial community of the underlying humus. Oikos 2000, 89, 231-242. [CrossRef]

59. Mia, S.; van Groenigen, J.W.; van de Voorde, T.F.J; Oram, N.J.; Bezemer, T.M.; Mommer, L.; Jeffery, S. Biochar application rate affects biological nitrogen fixation in red clover conditional on potassium availability. Agric. Ecosyst. Environ. 2014, 191, 83-91. [CrossRef]

60. Lehmann, J.; Rillig, M.C.; Thies, J.; Masiello, C.A.; Hockaday, W.C.; Crowley, D. Biochar Effects on Soil Biota-A Review. Soil Biol. Biochem. 2011, 43, 1812-1836. [CrossRef]

61. Vanek, S.J.; Thies, J. Pore-Size and Water Activity Effects on Survival of Rhizobium tropici in Biochar Inoculant Carriers. J. Microb. Biochem. Technol. 2016, 8, 296-306. [CrossRef]

62. Zahran, H.H.; Räsänen, L.A.; Karsisto, M.; Lindström, K. Alteration of lipopolysaccharide and protein profiles in SDS-PAGE of rhizobia by osmotic and heat stress. World J. Microbiol. Biotechnol. 1994, 10, 100-105. [CrossRef] [PubMed]

63. Elbl, J.; Plošek, L.; Kintl, A.; Hynšt, J.; Záhora, J.; Charousová, I. Effects of Drought on Microbial Activity in Rhizosphere, Soil Hydrophobicity and Leaching of Mineral Nitrogen from Arable Soil Depending on Method of Fertilization. Int. J. Agric. Biosyst. Eng. 2014, 8, 844-850.

64. Hueso, S.; García, C.; Hernández, T. Severe drought conditions modify the microbial community structure, size and activity in amended and unamended soils. Soil Biol. Biochem. 2012, 50, 167-173. [CrossRef]

65. Siczek, A.; Lipiec, J. Impact of faba bean-seed rhizobial inoculation on microbial activity in the rhizosphere soil during growing season. Int. J. Mol. Sci. 2016, 17, 784. [CrossRef]

66. Fall, D.; Bakhoum, N.; Nourou Sall, S.; Zoubeirou, A.M.; Sylla, S.N.; Diouf, D. Rhizobial Inoculation Increases Soil Microbial Functioning and Gum Arabic Production of 13-Year-Old Senegalia senegal (L.) Britton, Trees in the North Part of Senegal. Front. Plant Sci. 2016, 7, 1355. [CrossRef] [PubMed] 
67. Saito, M.; Marumoto, T. Inoculation with arbuscular mycorrhizal fungi: The status quo in Japan and the future prospects. Plant Soil 2002, 244, 273-279. [CrossRef]

68. Warnock, D.D.; Lehmann, J.; Kuyper, T.W.; Rillig, M.C. Mycorrhizal responses to biochar in soil-Concepts and mechanisms. Plant Soil 2007, 300, 9-20. [CrossRef]

69. Geisseler, D.; Horwath, W.R. Regulation of extracellular protease activity in soil in response to different sources and concentrations of nitrogen and carbon. Soil Biol. Biochem. 2008, 40, 3040-3048. [CrossRef] 